\title{
Doprinos teorije Pierrea Bourdieua analizi procesa gentrifikacije ${ }^{1}$
}

\author{
Vera Backović \\ Univerzitet u Beogradu, Filozofski fakultet, Srbija \\ e-mail: vera.backovic@f.bg.ac.rs
}

SAŽETAK U radu se ukazuje na moguću primjenu Bourdieuove razuđene „teorije” u analizi procesa gentrifikacije. U procesu gentrifikacije dolazi do mijenjanja objekata, ili njihove namjene, na centralnim gradskim lokacijama, koju prati promjena socijalnih karakteristika ljudi kojima su ti objekti namijenjeni. Mogu se razlikovati dva tipa gentrifikacije: pionirska gentrifikacija i profitabilna gentrifikacija.

Nastanak, širenje i modifikacija procesa gentrifikacije mogu se promatrati kao ishod djelovanja društvenih polja. Gentrifikacija se može sagledati kao razlikovanje, tada Bourdieuova klasna analiza omogućava određenje klasne pripadnosti gentrifikatora, kao i uočavanje njihove unutrašnje diferencijacije. Posebna pažnja u radu posvećuje se ulozi koju imaju različite vrste kapitala (kulturni, ekonomski, socijalni i simbolički kapital) u procesu gentrifikacije.

Ključne riječi: pionirska gentrifikacija, profitabilna gentrifikacija, životni stil, kulturni kapital, ekonomski kapital.

1 Tekst je rezultat rada na projektu Izazovi nove društvene integracije u Srbiji: koncepti $i$ akteri (broj 179035), koji realizira Institut za sociološka istraživanja Filozofskog fakulteta u Beogradu uz financijsku podršku Ministarstva prosvete i nauke Republike Srbije. 


\section{Uvod}

Namera ovog rada je da ukaže na moguću primenljivost teorije Pjera Burdijea u analizi procesa džentrifikacije. Iako je postindustrijsko društvo, u odnosu na društvo koje je proučavao Burdije, više potrošačko, u kome su stilovi života različitiji, pa se stoga može diskutovati o smanjivanju njihove klasne uslovljenosti i manjoj homogenosti, Burdijeova perspektiva, donekle izmenjena, omogućava analizu i savremenih fenomena, kao što je džentrifikacija. Kako je Burdije istakao umetnost i umetnička potrošnja predodređeni su da obavljaju društvenu funkciju ozvaničavanja društvenih razlika (Burdije, 2013.:13).

Džentrifikacija se izdvaja kao jedna od karakteristika postmodernog grada (Hanington, 1995.) i savremenog neoliberalnog urbanizma (Smith, 2002.). U procesu džentrifikacije dolazi do menjanja samih (stambenih) objekata, ili njihove namene (ako do tada nisu sadržali stambenu funkciju), na centralnim gradskim lokacijama, koju prati promena socijalnih karakteristika ljudi kojima su ti objekti namenjeni. Objašnjenja džentrifikacije mogu se podeliti u dve grupe u zavisnosti da li se u njima polazi od ponude imovine koja se može džentrifikovati (uslovljene strukturnim promenama - restrukturiranjem urbane ekonomije - kruženjem kapitala) ili delanja (izbora) aktera koji stvaraju ili koriste džentrifikovane prostore (Backović, 2016.). Pojam džentrifakatori u ovom radu odnosi se na aktere tražnje, na stanovnike džentrifikovanih susedstava, a ne na inicijatore procesa, koji mogu biti i akteri ponude iz privatnog ili javnog sektora. Kada je reč o pionirskoj džentrifikaciji, akteri procesa su uglavnom umetnici, pojedinci koji samostalnim akcijama menjaju radni i stambeni prostor i tako postepeno džentrifikuju susedstvo u kojem žive. U procesu profitabilne džentrifikacije susedstvo je već džentrifikovano ${ }^{2}$ pre nego što se doseljavaju pojedinci koji imaju viši ekonomski kapital u odnosu na pionire.

Iako se džentrifikacija povezuje sa strukturnim promenama (porastom servisne i kreativne klase), više pažnje u analizi se posvećuje osobenom životnom stilu džentrifikatora. ${ }^{3}$ Stil života čine različite kulturne prakse (odlasci u pozorišta, muzeje, galerije, čitanje knjiga, posedovanje umetnina ili sviranje instrumenta), kao i drugi izbori koji imaju simbolički aspekt - izbor nameštaja, dekorisanje doma, briga prema telu, način pripreme hrane, vaspitanje dece. Za simboličko diferenciranje, pored praksi, važni su i sudovi o sopstvenim praksama i praksama drugih, o lepom i ružnom, primerenom i neprimerenom (Spasić, 2006.:140). U Distinkciji klasu Burdije prepoznaje u koherentnosti izbora umetničkih dela, odlaska na odmor, ishrane, odevanja, ali i estetskih i moralnih sudova koji prate svaki od ovih izbora (Burdije,

2 Prostor može biti džentrifikovan od strane pionira, privatnog sektora koji investira u potencijalno profitabilnu lokaciju ili javnog sektora.

3 Novi rezidencijalni model, pored strukturne uslovljenosti, u vezi je i sa drugačijim stilom života servisne klase. Kao osobenosti tog životnog stila navode se hedonistički individualizam, odlaganje i/ili odbacivanje braka i/ili roditeljstva i izrazita prostorna mobilnost (česta promena mesta stanovanja i rada) usled nestandardne radne karijere. Florida navodi da se pripadnici kreativne klase u gradu ponašaju kao turisti u pogledu broja i sadržaja koje od grada „traže“. Pored poslovnih mogućnosti važni su kulturni, zabavni i rekreativni sadržaji, kao i njihova blizina (Petrović, 2009.:119-120). 
2013.). Burdijeove ideje uglavnom se koriste u analizi promena životnog stila pripadnika nove srednje klase u radovima Leja (Ley) i Bridža (Bridge).

Iz složene analize ukusa i životnih stilova u francuskom društvu mogu da se izdvoje sledeća Burdijeova zapažanja koja doprinose boljem sagledavanju fenomena džentrifikacije: društveno uslovljen ukus nije samo mogućnost da se prepozna kvalitet, već i sposobnost da se sudi o estetskim vrednostima; borbe oko nametanja određenog, specifičnog ukusa kao dominantnog su konstantne; usled promena u određenom društvenom polju menjaju se i habitus i ukus; stilizacija životnog stila uslovljena je vrstom i količinom kapitala koju pojedinci poseduju (Burdije, 2013.). Osim toga, njegovo shvatanje društvenog prostora, funkcionisanja polja i njihovih međuodnosa, veza habitusa, ukusa i stila života - omogućava da se fenomen džentrifikacije sagleda ne samo kao poseban životni stil usled menjanja habitusa nekih pripadnika srednje više klase, već i šire kao posledica odnosa između različitih polja (ekonomskog, umetničkog, polja stilova života i polja nekretnina).

\section{Džentrifikacija kao proizvod delovanja društvenih polja}

Prvo je potrebno ukazati na koji način prema Burdiju funkcionišu različita polja i kako se uspostavljaju društveni odnosi u njima. Polje označava prostor gde permanentno postoje međusobno suprotstavljene (društvene) sile koje se bore za prevlast. Iako su ekonomski i kulturni kapital konstitutivni za društveni prostor u celosti, određena polja (podsistemi) se strukturiraju oko akumulacije nekog specifičnog kapitala - političkog, naučnog, religijskog itd. Kako je polje strukturisana celina pozicija koje zauzimaju pojedinci, grupe i institucije na osnovu relevantnog kapitala, borbe koje se odvijaju u polju su oko akumulacije tog kapitala, ili za njegovo redefinisanje (Birešev, 2014.). Svaki društveni odnos prema Burdijeu određen je strukturom društvenog prostora koji se uspostavlja na osnovu količine ekonomskog i kulturnog kapitala, strukturom određenog društvenog polja tj. relacijama između pozicija unutar datog polja i nejednakom distribucijom kapitala koji se smatra važnim u datom polju (Birešev, 2014.:22). U svakom polju uspostavlja se hijerahijski odnos između nadređenih, dominantnih (poseduju više kapitala i kombinaciju kapitala koja se vrednuje u datom polju), i podređenih, dominiranih (poseduju manju količinu i neodgovarajuću kombinaciju kapitala). „Borbe” između dominantnih i dominiranih odvijaju se i u simboličkom prostoru kao borbe klasifikacija u kojima akteri (društveni dejstvenici) teže da izbore veću relativnu vrednost onih kapitala koje poseduju tj. za simbolički kapital (Birešev, 2014.).

Polja se međusobno rangiraju na osnovu mogućnosti da nametnu sopstvenu logiku i svoja pravila funkcionisanja drugim poljima. ${ }^{4}$ Naime, ona ostvaruju samo relativnu

4 Autonomija umetničkog polja zavisi od sposobnosti polja da se odbrani od uticaja ekonomskih kriterijuma, tj. da se vrednost umetničkog dela uspostavlja na osnovu umetničkih kriterijuma. Iako se ne zanemaruje uticaj ekonomske uspešnosti ona nužno ne znači uspeh u simboličkom smislu. U slučajevima kada princip spoljašnje hijerahizacije postaje dominantan, kada ekonomski uspešni umetnici počnu da nameću svoju definiciju umetnosti i umetničke izvrsnosti autonomija umetničkog polja je narušena i ugrožena (Birešev, 2014.:211-212). 
autonomiju, iako između njih ne postoji apsolutna dominacija, prisutna je mehanička veza (akcija, reakcija) i strukturalna veza (odnosi homologije, privremene dominacije...) (Birešev, 2014.). Dinamika odnosa aktera unutar polja može se posmatrati i iz perspektive odnosa datog polja s drugim poljima. U slučajevima kada dolazi do uticaja drugog polja i njegove logike na rangiranje aktera (dominantnih i dominiranih) hijerarhija polja se udvaja - uspostavlja se hijerarhija na unutrašnjim principima, ali i druga na principima koji su „uvezeni“ iz nekog drugog polja (Birešev, 2014.:63). Uspostavljeno je specifično stanju u polju moći ${ }^{5}$, iako to nije trajno stanje, neoliberalizam je doveo ekonomsku logiku na vrh, omogućivši joj upliv u druga polja (polja umetnosti, nauke, politike...). U tim uslovima na dominantnom polu polja je ekonomsko polje, tako da je ekonomski kapital „dominantan princip hijerarhizacije“, ali Burdije zapaža da i kulturni kapital ima određenu strukturišuću snagu, i da može biti princip hijerahizacije jer kulturni kapital širi svoj uticaj i na ostala polja (Birešev, 2014.:239). Džentrifikacija može da se posmatra kao potvrda širenja uticaja i značaja koji kulturni kapital ostvaruje u ekonomskom polju usled sve većeg razvoja industrije kulture i simboličke ekonomije (Zukin, 1991.). Posledice ovih promena u ekonomiji su da kulturni kapital sve više utiče na ekonomski kapital, mobilizacijom kulture i umetnosti ostvaruju se ekonomski rast i profit. Profesionalna aktivnost prvih džentrifikatora je veoma važna za savremenu ekonomiju jer imaju veliki uticaj na proizvodnju i potrošnju značenja. Posebno u oblikovanju popularne kulture, oni čine kreativno jezgro masovnih medija, industrije kulture i zabave i marketinga.

Međutim, širenje uticaja tržišta predstavlja pretnju autonomiji umetničkog polja. Strukturalna podređenost u polju umetnosti se nameće akterima u zavisnosti od njihove pozicije u okviru polja koja se uspostavlja uz pomoć dva osnovna posrednika: tržišta koje deluje direktno i indirektno (bilo preko prodatih dela ili putem novih radnih mesta koja se otvaraju) i trajnih veza/socijalnog kapitala (sličan način života i vrednosti, posećivanje mesta ${ }^{6}$ na kojima se dolazi u kontakt sa ljudima koji mogu da utiču na obezbeđivanje nekog izvora finansiranja7) (Burdije, 2003.:78). Burdije prepoznaje već u drugoj polovini 19. veka da štampa (urednici listova i novinari) može imati efekat strukturalne dominacije. U drugoj polovini 20. veka prvi džentrifikatori povezujući aktivnosti, kao sto su stanovanje, šoping i kulturne aktivnosti - od restorana do umetničkih galerija, položili su temelj za džentrifikaciju kojom je rukovodio privatni sektor - profitabilnu džentrifikaciju (Zukin, 1995.). Nastanak i širenje džentrifikacije može se objasniti promenama i delovanjima u različitim poljima, na preseku polja tržišta nekretnina, koje funkcioniše na principima koje je istakao Smit (Smith, 1979.), polja životnih stilova, polja umetnosti i polja ekonomije.

Iako se uspešnost na tržištu izdvaja kao kriterijum vrednosti i dalje postoji jedna razvijena „mreža“ posrednika koji su potpora tog uspeha, čiji uticaj je daleko od zane-

5 Polje moći je metapolje, arena u kojoj se odvija borba svih polja za prevlast - svako polje pokušava da nametne „svoj“ kapital i princip hijerarhizacije.

$\mathbf{6}_{\text {Uloga koju su nekada imali saloni. }}$

${ }^{7}$ Kao i zadobijanje naklonosti pripadnika ekonomske elite. 
marljivog. Osim što učestvuju u kreativnom stvaranju, prvi džentrifikatori su i fleksibilniji u prihvatanju raznoraznih novina u svom svakodnevnom životu čime stvaraju stil života koji posle izvesnog vremena postaje predmet imitiranja. Industrija medija ima ključnu ulogu u njegovoj popularizaciji. Posebno su prijemčivi za različite savete u vezi sa modom, muzičkim stilovima, ishranom, izgledu nameštaju, pojedinci koju su iskorenjeni usled profesionalne i prostorne mobilnosti (Čejni, 2003.:85) - pripadnici servisne klase. Kako je trend prostorne mobilnosti sve veći i informacione/ digitalne tehnologije sve naprednije i dostupnije, uticaj onih koji „tumače“ promene su sve značajniji i sveobuhvatniji. Predlozi i sugestije stručnjaka nalaze se u časopisima i drugim medijima (posebno blogovima) koji nude mnogobrojne savete u vezi sa načinom života. Većina džentrifikatora su upravo ti stručnjaci koji oblikuju ukus i navike. Mnoge od njih, između ostalog, interesovala je hrana i umetnost - tipovi kulturne potrošnje koju su uporedo rasli sa džentrifikacijom. Nezaposleni umetnici, kao i part time zaposleni razni izvođači, često su nalazili posao u novim prodavnicama hrane, restoranima, barovima i umetničkim galerijama. Pisci, koji su takođe stanovali u ovim susedstvima, pisali su o tom stilu života u novinama i časopisima. Prvi džentrifikatori obezbedili su materijalnu bazu i za novu kulturnu produkciju i za potrošnju ${ }^{8}$. Važnu ulogu u stvaranju i promovisanju urbanog životnog stila igraju mediji svih vrsta (TV, Internet, novine, radio, časopisi, serije, filmovi), koji su omogućili širenje (profitabilne) džentrifikacije. Kako urbani životni stil postaje poželjan, uključuje se privatni sektor (Zukin, 1991.).

U pogledu polja životnih stilova, slučaj džentrifikatora je osoben jer ovaj sloj jednim delom svoje legitimacijsko uporište nalazi u umetničkom polju, i to na dva načina. Prvo, džentrifikatori su objektivno vezani za umetničko polje, bilo direktno zaposlenje/aktivnost, ili kroz uključenost u različite mreže u svetu umetnosti. Drugo, oni svojim životnim stilom podržavaju „princip” i „kapital” umetničkog polja. Pitanje koje zahteva dodatnu analizu je u kojoj meri se odvija borba umetničkog i ekonomskog polja, ili se radi o nekoj sinergiji ova dva polja.

Koncentracija prvih džentrifikatora na određenom prostoru, koja je postepeno vodila transformaciji susedstva u skladu sa njihovim preferencijama životnog i radnog prostora, može se objasniti Burdijeovim shvatanjem globalnog društvenog prostora. Akteri su u globalnom društvenom prostoru podeljeni horizontalno prema obimu (ekonomskog i kulturnog) kapitala koji poseduju, i vertikalno prema zastupljenosti različitih vrsta kapitala u obimu njihovog kapitala (Burdije, 1998.). Pojedinci koji u društvenom prostoru zauzimaju bliske položaje postavljeni u slične uslove, i podvrgnuti sličnom uslovljavanju, i postoji velika verovatnoća da imaju slične sklonosti i interese, dakle da deluju na isti način (Burdije, 1998.:147-148). Odnos društvenog

8 Ove „slike” stvaraju su u gradu - na ulici, u reklamnim biroima i foto studijima, a zatim se šire dalje putem medijske mreže. Umetnici, dizajneri novih medija, feministkinje, gej osobe i parovi bez dece koji osmišljavaju ove slike predstavljaju najvidljivije protagoniste novih urbanih životnih stilova. Većina muškaraca i žena žive u nekom prostoru između slike - koju su politike identiteta i časopisi o životnim stilovima nametnuli poslednjih 30 godina, i želje da žive što je moguće bolje u njihovim susedstvima. Na njihove životne stilove, takođe, sve više utiču standardizovani prostori potrošnje (Zukin, 1998.). 
i geografskog prostora je takav da pojedinačni akteri, grupe ili institucije koje se u njemu nalaze imaju toliko više zajedničkih osobina što su bliže u tom prostoru, utoliko manje što su udaljeniji. Iako je gotovo svuda moguće posmatrati sklonost ka segregaciji u prostoru, ljudi koji su bliski u društvenom prostoru teže da budu bliski - hteli to ili ne - i u geografskom prostoru (Burdije, 1998.:146).

\section{Određenje klasne pripadnosti džentrifikatora}

Još jedno od pitanja koje se postavlja je kako odrediti društveni položaj aktera džentrifikacije. Za džentrifikatore se u literaturi obično uopšteno navodi da su pripadnici nove srednje klase, jer su oni u najvećem broju slučajeva stručnjaci različitih obrzovnih profila, pa se svrstavaju u servisnu ili kreativnu klasu (Florida, 2002.; 2005.). Pripadnici servisne klase ostvaruju autonomiju u profesionalnom radu na osnovu svojih kvalifikacija - stručnog znanja. U kreativnu klasu Florida svrstava ${ }^{10}$ sve visokoobrazovane pojedince koji obavljaju kreativna zanimanja, ona zanimanja u kojima se stvaraju nove forme. ${ }^{11}$

Prema Burdijeu za postojanje klase nisu dovoljni objektivni pokazatelji - visina prihoda, stepen obrazovanja i zanimanje - već se o klasama može govoriti samo u slučaju kada postoji samodoživljavanje njihovih pripadnika, koje prati osoben skup

9 Redfern u određivanju društvenog položaja džentrifikatora polazi od statusnih grupa. Džentrifikatori, koristeći način stanovanja kao statusni simbol, definišu i potvrđuju članstvo u toj statusnoj grupi. Džentrifikatori i pripadnici srednje klase koji žive u suburbiji su članovi različitih statusnih grupa a ne klasa jer džentrifikacijsko ponašanje nije uslovljeno njihovim klasnim položajem već mogućnostima. Redfern, naime, ističe da džentrifikatori džentrifikuju ne zato što moraju, već zato što mogu, povezujući džentrifikaciju prvenstveno sa pitanjima identiteta. „Borbe” u džentrifikaciji odnose se na pitanje identiteta u uslovima modernosti. Sledeći Vebera, statusne grupe u društvenom poretku, u sferi distribucije časti, teže da monopolizuju ugled, priznanje i poštovanje. Okruženi strancima ljudi teže da im se prizna izvesna individualnost, ali uporedo nastoje da uspostave odnose poverenja. Iako se prikazuju kao različiti, ne ističu to previše, jer, ipak, teže da se uklope u sredinu. Razrešenje ove tenzije između različitosti i konformizma nalazi se u domenu mode. U svetu mode se traži prepoznavanje, čast i poštovanje. Razlika između džentrifikatora, stanovnika suburbije i preseljenih, nije u motivaciji nego u sredstvima koja su im na raspolagnaju da dostignu željeno. Različitost džentrifikatora tako se ispoljava u potrošnji i životnom stilu (Redfern, 2003.).

10 U kreativnu klasu na početku 21. veka u SAD spada 38,3 miliona, 30\% radne snage, u odnosu na 20\% 1980. godine i 10\% na početku 20. veka (Florida, 2005.).

11 Među njima oni koji su zaposleni u naprednim uslugama mogu se svrstati u servisnu klasu. U okviru kreativne klase Florida razlikuje dve podgrupe: super-kreativno jezgro i kreativne stručnjake. U prvu grupu spadaju zanimanja koja stvaraju inovativne proizvode koji imaju široku primenu (npr. softveri ili muzičke kompozicije): naučnici, inžinjeri, univerzitetski profesori, pesnici, pisci, umetnici, zabavljači, glumci, dizajneri, arhitekte, kao i kreatori javne misli: novinari, urednici, ličnosti iz kulture, savetnici za društvena pitanja, polički i ekonomski analitičari (Florida, 2005.). Druga grupa, kreativnih stručnjaka, uključuje profesije koje se bave kreativnim rešavanjem problema i pronalaženjem novih rešenja: finansijske usluge, zdravstvenu zaštitu, pravne poslove i poslovni menadžment (Florida, 2002.). 
postupaka, praksi, navika i izbora (Spasić, 2006.:139-140). Burdije posebno ističe važnost kategorije ukusa za grupni identitet pošto jednu klasu objedinjuje neposredna privrženost određenim ukusima i anti-ukusima, simpatijama i averzijama, koje su upisane u najdublje slojeve habitusa. Ukus Burdije definiše kao sklonost i sposobnost za (materijalno i/ili simboličko) prisvajanje jedne određene klase klasifikovanih i klasifikujućih objekata ili praksi. Ukus je generativna formula za konstituisanje stila života - sklop distinktivnih preferencija koje, u okviru specifične logike svakog od simboličkih podprostora ... izražavaju istu ekspresivnu nameru. Kao klasni ukus definiše se negativno, kao odbijanje, čak i gađenje prema drugim ukusima. Pošto se ukus manifestuje kroz niz izbora koji su suštinski simboličke, kulturne prirode, Burdijeov pristup sadrži elemente kulturalističkog shvatanja klase (Spasić, 2006:140). Sklonost i težnja ka prisvajanju (materijalnom i/ili simboličkom) jedne određene vrste predmeta ili klasirajućih i klasiranih praksi, jeste ona generička formula koja stoji u osnovi stila života, jedinstvena celina onoga čemu čovek daje prednost pri izboru i što ga razlikuje od drugih. Bez obzira da li se odnosi na nameštaj, odeću, govor... (Burdije, 2004.:135). Iako ukus, koji je u osnovi sistema distinktivnih crta, predstavlja ishod kulturno naučenog, formira se tako da suštinski prikriva sopstvenu društvenu genezu. U pozadini estetičkih borbi, prema Burdijeu, je borba za nametanje jednog određenog „umeća življenja” kao jedino legitimnog (Spasić, 2006.:145). Ukus kao sistem obrazaca klasifikacije (kroz društvena uslovljavanja koja su ga proizvela) objektivno se odnosi na jedno društveno stanje: akteri se sami klasifikuju, sami se izlažu klasifikaciji, birajući u skladu sa svojim ukusima, različite atribute, odeću, hranu, piće, sport, prijatelje koji pristaju jedni drugima, i njihovom položaju. Oni biraju u prostoru dostupnih dobara i usluga, ona dobra čiji položaj u tom prostoru odgovara položaju koji akteri zauzimaju u društvenom prostoru. To je ono što čini da ništa ne klasifikuje nekoga tako kao njegove klasifikacije (Burdije, 1998.:151). Sledeći Burdijeov pristup ako se klasa defininiše preko ukusa, onda se džentrifikatori mogu smatrati pripadnicima jedne frakcije unutar srednje klase.

Važno je još istaći da svaka grupa nastoji da prilikom samopredstavljanja i samodefinisanja u prvi plan istakne svoje najbolje svojstvo i sistem klasiranja koji je za nju najpovoljniji ${ }^{12}$, jer uspostavljena načela hijerarhizacije nisu fiksirana, već su i ona predmet društvenih borbi (Spasić, 2006.:141). Pioniri džentrifikacije svoj sistem klasiranja ne nameću direktno, međutim, medijska potpora i nastupanje profitabilne džentrifikacije stavljaju ga u prvi plan. Može se uočiti da se životni stil džentrifikatora pokazuje iako ne kao najbolji, svakako kao jedan od poželjnijih.

Kako je identitet svake klase suštinski određen njegovom distancom ili odvojenošću od drugih grupacija, od karakteristika grupe postaju značajnija njena relaciona svojstva, koja nastaju na osnovu njenog položaja u sistemu razlika: grupa se definiše i svim onim što nije, a posebno onim čemu se suprotstavlja (Spasić, 2006.). Društveni identitet se definiše i potvrđuje u razlici (Burdije, 2013.:180). Jedna od važnih

12 Burdije posebno analizira intelektualce (profesore univerziteta, umetnike i priznate kulturne radnike) i njihovu ulogu u konstruisanju pravila društvenog hijerarhisanja, i osmišljavanja ideologije koja pravda postojeće društvene nejednakosti (simboličko nasilje) (Spasić, 2006.). 
odrednica džentrifikatora je njihovo suprotstavljanje suburbiji, kako životnom stilu njihovih stanovnika, sadržajima koje nudi, tako i samom vizuelnom izgledu (Ley, 1996.). Preseljenje na centralne gradske lokacije prvih džentrifikatora ${ }^{13}$ može se posmatrati kao kulturni pokret koji odbacuje životni stil predgrađa, odvojenost doma i radnog mesta, poistovećivanje uloge žene sa ulogom domaćice, masovne proizvode i prihvata umetnički stil života. U tom periodu, mediji ističu estetsku i istorijsku vrednost objekata i mesta koji se džentrifikuju. Javnost, u izvesnom smislu, shvata džentrifikaciju na estetski način, kao umetnički životni stil (Zukin, 1989.).

U pogledu određenja klasne pozicije džentrifikatora može se slediti Burdijeovo shvatanje društvene strukture, ali treba imati u vidu da prema njegovom shvatanju džentrifikatori ne bi spadali u srednju klasu, već u dominantnu - vladajuću klasu. Burdije razlikuje tri klase: dominantnu, srednju i narodsku (seljaci i radnici). U okviru dominantne klase Burdije razlikuje dve frakcije dominantnu i dominiranu: krupnu buržoaziju i intelektualce. Prvi poseduju više ekonomskog kapitala, a drugi kulturnog kapitala ${ }^{14}$. Neki pripadnici nove srednje klase dele sa intelektualcima vrednovanje nematerijalnih vrednosti i otvorenost za novo. Oni nastoje da stilskim sredstvima uz mali trošak ekonomskih resursa, oblikuje svoj distinktivni položaj. Prema Burdijeu, buržoazija teži takvim praksama u kojima može da pokaže ekonomsku moć, dok intelektualci teže praksama koje zahtevaju niže materijalne troškove a imaju intelektualno-simboličku dobit. Ova razlika se iskazuje kroz diferencijalan pristup praksama kulturne potrošnje: buržoazija će izabrati „bulevarsko” pozorište, skupe karte i garderobu. Prilikom kupovine umetničkih dela biraće afirmisane umetnike, one koji su već poznati. Nasuprot njima, druga frakcija će izabrati avangradno pozorište i podržavaće umetnike koji su još uvek nedovoljno afirmisani (Spasić, 2006.:143).

Osim razlikovanja od drugih pripadnika srednje (više) klase džentrifikatori i sami nisu homogena grupa. Sledeći Burdijeovo razlikovanje frakcija u okviru klasa, i među akterima džentrifikacije se može napraviti razlika u zavisnosti od kapitala koje poseduju. Količina i vrsta kapitala, kao što je već rečeno, vodi diferencijaciji prakse u različitim domenima u kojima se posmatra stil života. Struktura i vrsta kapitala koju poseduju pioniri drugačija je od strukture kapitala stanovnika koji se u procesu profitabilne džentrifikacije doseljavaju. Pioniri poseduju više kulturnog kapitala od ekonomskog kapitala (ekonomski dominirani, kulturno dominantna frakcija). Među njima je značajan broj umetnika koji nastoje da razviju i istaknu svoj sofisticirani ukus i poseban stil života. U slučaju profitabilne džentrifikacije u susedstvo se doseljavaju pojedinci (ekonomski dominantni) koji poseduju više ekonomskog kapitala u odnosu na pionire. Akteri profitabilne džentrifikacije prihvataju ukus i životni stil

13 Doseljavanje je počelo kasnih 1950-ih, publicitet stiče tokom 1970-ih.

14 I u okviru srednje klase mogu se identifikovati dve grupe, princip podele je isti kao i u okviru dominantne klase samo pripadnici srednje klase raspolažu sa manjom količinom kapitala (Burdije, 2013.). Stara sitna buržoazija (zanatlije, sitni trgovci) i nova srednja klasa (kulturni posrednici, niži kadrovi državne službe i privatnog sektora). Ukus srednje klase se određuje kao „kulturna dobra volja” ili „alodoksija”, priznavanje legitimne kulture bez poznavanja iste (Spasić, 2006.:143). 
koji je već prepoznat kao popularan. Japiji koji su postali kulturni fenomen 1980ih, samo su preuzeli poziciju prvih džentrifikatora u urbanoj potrošačkoj hijerarhiji (Zukin, 1989.).

\section{Menjanje habitusa u procesu džentrifikacije?}

Burdije je dao više definicija habitusa a najčešće se navodi da je habitus sistem internalizovanih dispozicija koje posreduju između društvenih struktura i praktičnog delovanja usmeravajući njihove prakse i dajući im klasno prepoznatljivu formu i pravac. Habitus je ono što čini da su sve prakse jednog agensa (ili grupe agensa koji su proizvod sličnih uslova) istovremeno sistematične - utoliko što su one proizvod istovetnih (ili međusobno zamenljivih) obrazaca, i sistematski različite od praksi koje čine neki drugi stil života (Burdije, 2004.:132).

Burdije praksu aktera/dejstvenika prvo definiše kao proizvod dijalektičkog odnosa jedne situacije i jednog habitusa, uvođenjem polja u analizu praksu određuje kao rezultat susreta jednog polja i jednog habitusa (Birešev, 2014.:63-64). Ulaskom u polje habitus aktera je pod uticajem osnovnih pretpostavki, vrednosti, normi ${ }^{15}$ (tog polja) tako se on menja usled usvajanja specifičnih dispozicija i razvija u pravcu jednog habitusa polja. Habitus svakog aktera prilagođava se nameravanim i kontrolisanim promenama, ali i onim polusvesnim, habitusu polja. Habitus nekih pripadnika srednje klase se menja tokom procesa džentrifikacije. Praksa džentrifikatora može da se posmatra kao interakcija specifičnog habitusa i strukture različitih polja. Ponašanje prvih džentrifikatora (pionira) može se smatrati racionalnim, njihovo ponašanje je podstaknuto niskom cenom nekretnina u susedstvima na centralnim gradskim lokacijama i blizinom radnih mesta (Zukin, Lay, Smith). ${ }^{16}$

Kako Birešev navodi, habitus je struktura koja je sastavni deo jedne posebne vrste okruženja, kao što su materijalni uslovi postojanja karakteristični za jedno klasno stanje. Naime, delanje svakog pojedinca usmereno je izvesnim implicitnim principima koji upravljaju i ponašanjem ostalih pripadnika zajednice, ali moguća su ne-

$\mathbf{1 5}$ Logika polja, interna pravila, nomos polja do koga se dolazi postepeno, kroz prakse, svakodnevne rutine.

16 Rouz ističe značaj džentrifikacije za društvenu reprodukciju marginalno zaposlenih, visokoobrazovanih, koji žele da žive u centru grada i jeftino stanuju, iz socijalnih ili ekoloških razloga. Rouz odbacuje svođenje alternativnog životnog stila na modu već ukazuje da drugačiji životni stil predstavlja odgovor obrazovanih ljudi na nove uslove plaćenog i neplaćenog rada (nezaposlenost, privremenu ili part-time zaposlenost) u sve težim ekonomskim uslovima. Njihova koncentracija u unutrašnjim delovima grada može im omogućiti realizovanje nekog vida samozapošljavanja (rad kod kuće) ili učestvovanje u nekim „neformalnim” aktivnostima. Tako Rouz izdavaja ekonomski razlog, visoku cenu stanovanja u predgrađu (za jednoroditeljske porodice ili singl pojedince), kao i nemogućnost vođenja netradicionalnog stila života u konvencionalnoj sredini (posebno se odnosi na gej populaciju). Osim dostupnosti stanova po nižoj ceni, Rouz naglašava i važnost razvijene neformalne mreže čuvanja dece za jednoroditeljske porodice (Rose, 1984.). 
znatna odstupanja jer ih svaki pojedinac kombinuje na osobeni način, i u zavisnosti od toga ko mu je, i kako uputio izazov. Usklađeni habitusi proizvode prakse koje su usklađene tek toliko da održavaju igru oko koje se organizuje život zajednice, ali prakse predstavljaju relativno nepredvidljive improvizacije u predvidljivim okvirima (Birešev, 2014.:52). Odnosi unutar umetničkog polja, ekonomskog polja i polja trŽišta nekretnina, kao i njihovi međusobni odnosi, se menjaju i inicira se pionirska džentrifikacija, proces u kojem se menjaju prakse jednog broja pripadnika srednje klase. Vremenom se odnosi ponovo menjaju usled promene „slike“ o susedstvu ${ }^{17}$, jačanja uticaja ekonomskog polja na umetničko polje, porasta cena nekretnina - komercijalizacijom pionirske džentrifikacije nastaje profitabilna džentrifikacija.

Polazeći od Burdijea, Bridž džentrifikaciju posmatra velikim delom kao nesvesni odgovor na novo polje mogućnosti u odnosima između kulturnog i ekonomskog kapitala u društvenom prostoru (Bridge, 2001b.:206). Mogućnosti su nastale jer su se promenili ekonomski uslovi (pad cena zemljišta i nekretnina na određenim gradskim lokacijama, uslovi investiranja; ali i strukturne promena: porast servisne klase). Usled promena u polju umetnosti, polju tržišta nekretnina i ekonomskom polju džentrifikacija nastaje kao odgovor na novonastale ekonomske i društvene mogućnosti koje se rađaju iz prethodnih dispozicija klasnog habitusa.

U slučaju prvih džentrifikatora njihovo razlikovanje se manifestuje u vrsti susedstva koje biraju, stanovanju, potrošnji i životnom stilu. Estetska prepoznatljivost i sklonost koje su nužno prisutne u kulturnom diskursu privilegovanih čine deo habitusa onih koji imaju simboličku prevlast. Osim toga, druga važna karakteristika je da su oni koji poseduju kulturni kapital dovoljno vešti i samouvereni da eksperimentišu pomerajući granice proverenog ukusa (Čejni, 2003.:81-86).

Motivaciona snaga koja u slučaju džentrifikacije reprodukuje habitus je težnja njenih aktera da zadrže distinkciju koja se se odnosi na mogućnosti definisanja ukusa i istančanost, i na posedovanje retkih stvari u skladu sa njima. Džentrifikacija, takođe, uključuje svesne izbore u fizičkoj i društvenoj okolini, koje vrši nekolicina pripadnika srednje klase. Menjajući habitus oni mogu menjati principe budućih izbora (Bridge, 2001b.). Centralno gradsko područje se definiše kao poželjno, i kao znak razlikovanja, oslanjajući se na tradiciju elitnog dela grada iz perioda preindustrijskog kapitalizma. Ta promena simboličkog značaja centralnog gradskog prostora suprotstavlja se „Životu” radničke klase, kao i „predgrađu” srednje klase. Simboličko uređivanje prostora postaje nova klasna karakteristika. Sposobnost da se redefinišu vreme ${ }^{18} \mathrm{i}$ prostor je znak autoriteta, i praktikovanja klasne moći (Bridge, 2001b.). Džentrifikovani prostori vremenom postaju tražena i pomodna područja. Tako Redfern (2013.) ukazuje da je susedstvo Islington odjednom postalo moderno, jer je njegov stambeni fond postao sredstvo modnog izražavanja - izraz ličnosti. Arhitektura koja je smatrana za neinteresantnu postala je poželjna, iako se nisu promenili ni zgrade ni lokacija, već promenu predstavlja da je džentrifikatori koriste kao iskaz o sebi.

$\mathbf{1 7}$ Životni stil pionira postao je popularan, slika susedstva je pozitivna.

18

Estetizovana istorija susedstva predstavlja se kao autentična. 
Džentrifikacija tako postaje novi oblik razlikovanja. Burdije distinkciju vezuje za dominantnu klasu čiji stil života se naziva osećajem distinkcije. Materijalni položaj (ekonomski kapital) dominantne klase omogućava joj „distancu prema nužnosti” (nepostojanje brige za svakodnevnu egzistenciju), time ova klasa ima mogućnosti da se posveti ,višim” vrednostima koje se odnose na stilizaciju i estetizaciju života ${ }^{19}$ (Spasić, 2006.:142). Odlika estetike džentrifikacije je konstantno menjanje, granice estetike se stalno testiraju, nabavljanjem novih modernih dobara s jedne strane, i korišćenjem istorijskih simbola, s druge strane (Bridge, 2001b.).

Razlikovanje džentrifikora u odnosu na ostale pripadnike srednje klase, kao i pionira u odnosu na aktere profitabilne dežentrifikacije, bilo bi podsticajno ispitivati i u tri obalsti potrošnje - ishrani ${ }^{20}$, kulturi i prezentaciji (odeći, brizi o telu i proizvodima za negu). Burdije ukazuje na klasnu uslovljenost i vezu ukusa za hranu i postupanja prema telu, kao i na procenu uticaja koji hrana ostvaruje na telo (snagu, zdravlje, lepotu). Takođe, odeća, kozmetički proizvodi i korekcija izgleda tela (frizura, šminka, brada, brkovi) pokazuju da je i telo društveni proizvod (Burdije, 2013.:192-202).

Jednu razliku je još važno istaći, naime prema Burdijeu jedna od razlikovnih odlika distinkcije $^{21}$ je neupadljivost ${ }^{22}$. Spasić ističe da se Burdijeova distinkcija očituje kroz diskretnost, umerenost, uzdržanost ${ }^{23}$. Na delu je mehanizam naturalizacije, „oprirodnjavanja”, kojim se jedan ukus, stečen u sasvim partikularnim, društveno određenim okolnostima socijalizacije i predstavlja kao prirodan (Spasić, 2006.:144-145). Džentrifikacija kao proces, i ponašanje džentrifikatora su suprotni jer je „vidlijivost” važno obeležje njihovog životnog stila. Vidljivost njihovih estetskih praksi, okrenutost modi i trendovima, predstavlja suštinu džentrifikacijske estetike (Bridge, 2001b.), što je posebno izraženo u procesu profitabilne džentrifikacije. Takva praksa je na tragu

19 Sama kategorija „ukusa” je buržoaska ideja, koja je u vezi sa višim položajem jer uključuje mogućnost izbora, slobodu opredeljenja i prevazilazi materijalne i egzistencijalne nužnosti. Život niže klase, posebno narodske je „ukus nužnosti”, uslovno se radi o ukusu jer su pripadnici ove klase razvili želju da žele ono što je u skladu sa nužnošću, ono što je „Za njih” (Spasić, 2006.:142).

$\mathbf{2 0}$ Šta se jede, kako se jede i gde se jede - od izbora hrane, njenog serviranja (načina i izgleda) i nuđenja.

21 Distinkcija po definiciji označava diferenciranje, povlačenje granice prema drugima, ali u svoju korist: na način da se sebi (sopstvenoj grupi) pripiše superiornost (Spasić, 2006.).

$\mathbf{2 2}$ Osobeni mehanizam intelektualne distinkcije sastoji se od „bezinteresnosti”. Intelektualci teže da se pokažu kao ljudi koji teže onome što ne donosi neposrednu korist, to im donosi osećanje uzvišenosti (Spasić, 2006.:144).

$\mathbf{2 3}$ Čak, akteri koji zauzimaju više pozicije koriste strategiju „popustljivosti” kako bi simbolički negirali društvenu distancu, za šta dobijaju priznanje, iako ona objektivno postoji (Burdije, 1998.). 
Veblenove upadljive potrošnje ${ }^{24}$, i njegovog zaključka da je potrošnja ugledna ako je rasipnička (Veblen, 2008.). Za tradicionalnu buržoaziju estetsko je nešto što se podrazumeva, prećutno i nerefleksivno, dok su estetske prakse nove srednje klase javne i samosvesne. Ta klasna frakcija učestvuje u različitim formama refleksivne potrošnje, nekoj vrsti društvenog performansa, kao što su posećivanje određenih restorana, ali neformalna okupljanja u vinskim barovima i kafeima. Samosvest ovog kretanja potpomognuta je od strane „kritične infrastrukture” - restoratera, dizajnera enterijera, poznavalaca jela i vina - koja podržava i promoviše takve potrošačke navike. Habitus džentrifikatora je predmet samosvesne konverzije na svečanim obedima, novinskim kolumnama, časopisima i filmovima (Zukin, 1982.; 1991.). Performativnost refleksivnih praksi frakcije nove srednje klase podržava pozornica na kojoj se performans odigrava, a to je centralni gradski prostor. U ovom pogledu pripadnici ove klase upotrebljavaju novu prostornu strategiju za izražavanje svog klasnog habitusa ${ }^{25}$, imitirajući vreme kada je nekadašnja buržoazija imala kulturni zamah u centru viktorijanskog grada ${ }^{26}$ (Bridge, 2001b.).

\section{Uloga kulturnog, ekonomskog, socijalnog i simboličkog kapitala u procesu džentrifikacije}

U analizi nastanka i diverzifikaciji fenomena džentrifikacije primenjuju se vrste kapitala koje je uočio Burdije (kulturni, ekonomski, simbolički, socijalni) ${ }^{27}$, posebno

24 Prema Veblenovoj teoriji u svakoj visokoorganizovanoj zajednici osnova na kojoj počiva dobar ugled je novčana moć, a sredstva pokazivanja novčane moći i sticanja, ili zadržavanja, dobrog imena su dokolica i isticanje potrošnje robe. Sredstva saobraćaja i pokretljivost stanovništva uticali su na povećanje broja pojedinaca koji prosuđuju o nečijem izgledu na osnovu njegovog „izlaganja robe”. Sve veće isticanje potrošnje (naspram dokolice) posledica je težnje za impresioniranjem uzgrednih posmatrača ispisivanjem podataka o novčanoj moći takvim slovima koja će svakome bosti oči. Sklonost može da se manifestuje u vidu „društvenih obaveza", i u vidu kvaziumetničkih i kvazinaučnih postignuća, u brizi oko kuće i njenom ukrašavanju, aktivnostima oko šivaćih tečajeva i reformi odeće, u veštini odevanja, kartanja, jedrenja, igranja golfa i sl. Iz navedenog Veblen zaključuje: da bi potrošnja bila ugledna mora biti rasipnička (Veblen, 2008.:136-145).

25 Džentrifikacijski habitus, međutim, nije dostupan u gradovima sa nerazvijenom servisnom klasom, niti u gradovima u kojima je deindustrijalizacija isuviše velika, iz kojih stanovništvo migrira (Bridge, 2001b.).

26 Ne čudi što je jedna od strategija sadašnje srednje klase da „Vrati“ prošlo vreme kroz pokrete za očuvanje susedstva i brigom za urbano nasleđe (Ley, 1996.; Bridge, 2001b.).

27 Kao izvori društvene moći prepoznaju se ekonomski, kulturni kapital i socijalni kapital, ali i simbolički kapital, koji predstavlja oblik koji može imati svaka navedena vrsta kapitala u slučaju da je prepoznata i priznata kao legitimna. Prema Burdijeu (2013.) ekonomski kapital se odnosi na novčani prihod i druge finansijske resurse i aktivu, čiji su institucionalni izraz svojinska prava. Kulturni kapital ima dve karakteristike koje se analitički uočavaju, nivo obrazovanja/znanja, i simbolički oblik koji predstavlja sposobnost da se definišu i legitimizuju kulturne, moralne i estetske vrednosti, standardi i stilovi. Socijalni kapital se odnosi na zbir stvarnih i potencijalnih resursa koji se mogu mobilisati kroz članstvo u društvenim mrežama i organizacijama. 
forme kulturnog kapitala (institucionalizovani, objektivirani i otelovljeni) ${ }^{28}$, kao i njegovo shvatanje o mogućnosti konverzije kulturnog kapitala u ekonomski kapital.

- Institucionalizovani kulturni kapital (formalno obrazovanje) povezuje se sa pokretanjem procesa džentrifikacije; takođe, naglašava se njegova konverzija u ekonomski kapital na prelazu pionirske u profitabilnu džentrifikaciju. Pored navedenog delovanje ove forme kulturnog kapitala vidi se u vrednovanju školovanja dece ${ }^{29}$, koje zatim utiče na izbore i ponašanje džentrifikatora.

- Objektivirani kulturni kapital čine materijalni objekti koji imaju kulturnu vrednost (umetnička dela, knjige, muzički instrumenti, enterijer, nameštaj). U ovoj formi kulturnog kapitala manifestuje se džentrifikatorska estetika, koja deluje kao vidljiv klasni marker.

- Otelovljeni kulturni kapital, neakreditovan, čine dugotrajne dispozicije uma i tela (određeni stilovi, načini predstavljanja, upotreba jezika, oblici društvene etikecije i kompetencije, stepen samopouzdanja) (Tomanović, 2006.), i sposobnost uživanja u umetničkim delima. Ova forma kulturnog kapitala predstavlja manifestaciju džentrifikatorskog ukusa. Otelovljen kulturni kapital se reprodukuje u provođenju slobodnog vremena i potrošnji koji odražavaju norme društvenosti i njihov ukus.

Za objašnjenje ponašanja prvih džentrifikatora (Cameron i Coaffee, 2005.; Ley, 1996.; Zukin, 1998.) moguće je koristiti odnos materijalnog i kulturnog kapitala na koji je ukazao Burdije. Prvi džentrifikatori koristili su svoj kulturni kapital kako bi postigli različit životni stil. Kulturni kapital se u ovom slučaju posmatra kao sredstvo regeneracije prostora. Džentrifikovana susedstva viđena su kao prostorna manifestacija habitusa nove srednje klase (Ley, 1996.; Podmore, 1998.), a džentrifikacija kao njihova strategija razlikovanja. Kako oni poseduju manje količine ekonomskog kapitala, renoviranje i uređivanje objekta sproveli su sami. Dominirana frakcija teži uvećanju kapitala kroz prakse vezane za deo polja umetnosti - koji podrazumeva malu ekonomsku investiciju uz veliki simbolički „profit” (Filipović, 2014.:1024). Klasno razlikovanje u odnosu na pripadnike radničke klase u naselju pioniri potvrđuju manifestacijom objektiviranog kulturnog kapitala. I pored toga što se radi o manjim intervencijama na stambenim objektima one predstavljaju upadljiv i značajan signal različite estetike stanovanja. U ranoj fazi razlikovanje i pripadnost srednjoj klasi potvrđuju se krečenjem u odgovarajuću pastelnu boju (Bridge, 2006.).

Estetika džentrifikacije omogućava razlikovanje od ukusa pripadnika srednje klase koji žive u suburbiji, ali i od ukusa pripadnika radničke klase koji stanuju u centru

28

Pojedinci koji poseduju društvenu moć imaju monopol da klasifikuju objekte u skladu sa svojim kriterijumom dobrog ukusa, tako je mogućnost kreiranja novih sistema razlikovanja moć klasnog položaja, a klasne razlike se ispoljavaju i održavaju u svim oblicima kulturnog kapitala koje je izdvojio Burdije - institucionalizovanom, objektiviranom i otelovljenom kulturnom kapitalu.

29 Više o značaju jezičkog i kulturnog kapitala za klasnu reprodukciju u: Burdije i Paseron, 2014 
grada. Lej (Ley, 1996.) ističe potrošačke navike nove srednje klase koja više voli da kupuje ono što se njoj nudi kao ciljnoj grupi, nasuprot masovnoj potrošnji radničke klase $^{30}$ (Bridge, 2001b.).

Kako je proces odmicao, životni stil džentrifikovanih susedstava je privukao stručnjake zaposlene u privatnom sektoru, koji su posedovali više ekonomskog nego kulturnog kapitala. Određeni „simboli” u samom susedstvu, ili njegovoj neposrednoj blizini su, takođe, prepoznati kao važni za ove nove džentrifikatore. Ispitanici iz Batlerovog (Butler, 1997.) istraživanja u Londonu ukazuju kako je otvaranje prvog vinskog bara ili prodavnice delikatesa u susedstvu bilo presudno za njihovu odluku da se presele u to susedstvo. Ovi džentrifikatori se povezuju sa komodifikovanim oblicima džentrifikacije, posebno sa privatnim investicijama u pretvaranje industrijskih prostora u luksuzne stanove, po pravilu na obalama reka i mestima koja imaju simboličku vrednost (Zukin, 1989.; Podmore, 1998.).

Dok nivo kulturnog kapitala može nastavljati da raste, u pogledu obrazovnog nivoa stanovnika koji se doseljavaju (Ley, 1996.), strategije razvijanja kulturnog kapitala počinju da se menjaju. „Pokazatelji” koji su nekada bili izraz ukusa jedne frakcije komodifikuju se, što potvrđuje Burdijeovu ideju da ekonomski i kulturni kapital mogu da se razmenjuju jedan za drugi. U slučaju profitabilne džentrifikacije pošto se rutinizuju estetski aspekti procesa, kulturni kapital u vidu džentrifikatorske estetike, ulazi u ukupnu cenu imovine. Zukin je pratila ovu transformaciju kulturnog kapitala u ekonomski kapital u TriBeCa susedstvu (Triangle below Canal Street) u donjem Menhetnu (Zukin, 1989.; 1995.). Nakon deindustrijalizacije ove oblasti u Njujorku, prostor ${ }^{31}$ su zauzeli umetnici (skvotirali su ga ili plaćali minimalnu rentu za njega $)^{32}$. U tom trenutku, TriBeCa susedstvo ima veoma visok nivo kulturnog kapitala i nizak ekonomski kapital. Ali zbog reputacije kreativne boemije agenti za nekretnine predstavljaju ovu oblasti kao kreativnu, živopisnu, kao urbanu „ivicu”. Postojeći vlasnici primorani su da prodaju svoja potkrovlja koja se sve više pretvaraju u čisto stambeni prostor. Improvizovane galerije pionira zamenjene su većim, komercijalnim galerijama. I u slučaju ovog susedstva komodifikaciji je doprinela mreža restorana i umetničkih kritičara koji su pisali o životnom stilu Njujorka, obaveštavajući o otvaranju najnovijih restorana i galerija i aktivnostima u njima (Zukin, 1989.).

Uticaj ekonomskog kapitala u džentrifikovanim susedstvima potvrđen je i u Bridžovom istraživanju sprovedenom u Sidneju kasnih 1990-ih. Dok su razlike u ranim fazama procesa bile izvesne estetske adaptacije samih džentrifikatora u četvrtima Balmain i Glebe, kasnije se razlikovanje postiže investiranjem veće količine ekonomskog kapitala. Renoviranje stanova često se izvodi na osnovu arhitektonskih i

30 U literaturi o džentrifikaciji ne analizira se detaljnije ukus i habitus radničke klase.

$31 \mathrm{Na}$ svakom spratu se nalazio jedan nepodeljeni prostor sa velikim prozorima koji je bio idealan za studio ili atelje.

32 Vremenom zajednički ulaz ovih objekata je obeleženi natpisom AIR (artists in residence umetnici stanari) (Zukin, 1989.). 
dizajnerskih projekata, a zgrade imaju prestižni pogled u Sidneju - skyline centra ili mosta u luci. Jedan aspekt ovog oblika razlikovanja Bridge naziva premium (prvoklasna) džentrifikacija (Bridge, 2001b.) ukazujući da nivo investicija ekonomskog kapitala može prevazilaziti ono što je racionalno i utilitarno, pošto džentrifikacija u ovim elitnim susedstvima sve više postaje ekskluzivna upadljiva potrošnja. U ovim susedstvima, uspostavljena džentrifikatorska estetika predstavlja uslov za dalju upadljivu potrošnju doseljavanjem stanovnika koji poseduju visok ekonomski kapital i niži inovativni kulturni kapital (Bridge, 2006.).

Moć objektiviranog kulturnog kapitala je mogućnost redefinisanja siromašnih četvrti u vrednu imovinu, u sada poželjnim naseljima. U ovom procesu, kulturni kapital (moć da definiše i legitimiše) prevladava ekonomski kapital, ali kako džentrifikacija napreduje, balans se menja i ekonomski kapital počinje da stavlja pod svoje kulturni kapital (Bridge, 2006.).

Osim objektiviranog kulturnog kapitala i institucionalizovani kulturni kapital, takođe, može uticati na izbor susedstva za život, prvenstveno za pripadnike srednje klase koji su roditelji. Sa pojavom tržišta obrazovanja u Velikoj Britaniji, na izbor mesta stanovanja pripadnika srednje klase počinju da utiču planovi za školovanje dece. Veličina Londona im omogućava da razviju odgovarajuće strategije izbora srednje škole, koje mogu da realizuju i u okviru susedstva koje je u skladu sa džentrifikatorskom estetikom (unutrašnji viktorijanski okruzi). Bridž ukazuje i da različito raspoređivanje kulturnog kapitala u različitim oblastima može odgovarati životnom ciklusu džentrifikatora, jer postoje prostorno i vremensko raspoređivanje kulturnog kapitala. Prostorno raspoređivanje kulturnog kapitala uključuje džentrifikatorsku stambenu estetiku i prepoznatljivu potrošnju kao deo simboličkog preuređivanja centra grada. Vremensko raspoređivanje uključuje akumulaciju kapitala koja nije nužno tako brzo materijalizovana (ili konvertovana u ekonomski kapital). Manje je vidljivo, i više je u saglasnosti sa tradicionalnom strategijom srednje klase koja se odnosi na razlikovanje kroz obrazovanje - institucionalizovani kulturni kapital koji će biti realizovan u stepenu kvalifikacija dece (Bridge, 2006.).

Rezultati Bridžovog istraživanja ${ }^{33}$ pokazuju tenziju između institucionalizovanog kapitala (vrednovanje obrazovnih postignuća, značaj obrazovanja dece za pozicioniranje na tržištu rada koje omogućava reprodukciju položaja) i objektiviranog kulturnog kapitala (estetika džentrifikovanih susesdstva), koja se odigrava na nivou susedstva. Poredeći situaciju u Londonu i Bristolu, Bridž pokazuje da se u Londonu strategije izbora škole mogu sprovoditi uz održavanje džentrifikatorske estetike, ili čak zajedno sa džentrifikacijom (onih četvrti koje mogu da se „preurede“ u stilu

33 U istraživanje životnog toka džentrifikatora u Bristolu su uključeni pripadnici srednje klase koji su prodali imovinu u jednom džentrifikovanom susedstvu 2002/03. godine. Domaćinstva su intervjuisana u objektu koji je za prodaju, a gde je bilo moguće, i u naselju posle selidbe. Od ukupno 30 intervjuisanih, 10 domaćinstava koja su se preselila su pristala na drugi intervju. Intervju se bavio rekonstrukcijom stambene istorije svakog pojedinca (od rođenja do tog boravišta); doživljajem susedstva; renoviranjem kuće; razlozima za selidbu, strategijama potrage i odabira destinacije. 
viktorijanskog stanovanja). Nasuprot Londonu, situacija u Bristolu zahteva veći kompromis između objektiviranog i institucionalizovanog kulturnog kapitala, jer iseljavanje iz džentrifikovanih naselja znači odlazak na lokacije drugačije estetike. U tim slučajevima dugoročna ulaganja u institucionalizovani kulturni kapital „dobijaju" u odnosu na neposrednu investiciju u objektivirani kulturni kapital (Bridge, 2006.).

Bridžovo istraživanje je pokazalo da dinamike objektiviranog, institucionalizovanog i otelovljenog kulturnog kapitala (i njihovih odnosa sa drugim oblicima kapitala) rade na različitim vremenskim i prostornim nivoima. U džentrifikovanim naseljima, objektivirani kulturni kapital izgleda jak (u obliku džentrifikatorskog prikazivanja), ali ispod površine institucionalizovani kulturni kapital (naročito u izboru škole) može dovesti do toga da se džentrifikatori vraćaju konvencionalnom stilu životu u predgrađu. Isto tako, strategije doseljavanja u okolini dobrih škola u centru grada mogu podstaći džentrifikaciju tih susedstava. Osim toga, mogu postojati naselja koja se pokazuju kao kosmopolitska, i u kojima se čini da se održala socijalna različitost, ali koja su na nivou otelovljenog kulturnog kapitala (signali tela i način međusobne komunikacije) i dalje veoma segregirana (Batler i Robson, 2001.).

\subsection{Socijalni kapital džentrifikovanih susedstava}

Džentrifikacija predstavlja kako vidljivu prostornu, tako i identitesku zajednicu, jasno ocrtavajući svoje granice i ističući svoju različitost. Džentrifikovano susedstvo, kao proizvod postmodernog društva, pokazuje da prostorna koncentracija nije nužno napuštena uporedo sa porastom individualizacije.

Proces džentrifikacije pokrenut je tako što su prvi džentrifikatori bili deo razvijenih socijalnih mreža, oni su zapravo donosili odluke da se dosele u određeno susedstvo na osnovu preporuke prijatelja, i želje da stanuju blizu njih. Prema Batleru to je bio slučaj sa džentrifikacijom Hackney'a u Londonu, a i Bridžov rad je potvrdio da su socijalne mreže važno sredstvo regrutovanja za dežntrifikaciju (Bridge, 2001.a.; 2006.). Džentrifikovana susedstva pionira imala su razvijen socijalni kapital, kako se proces širio nastaju susedstva koja se razlikuju u pogledu kohezivnosti i razvijenosti socijalnog kapitala ${ }^{34}$ (Butler i Robson, 2001.) što se, takođe, dovodi u vezu sa obeležjima životnog stila koji se manifestuju u prostoru ${ }^{35}$ (Allen i Blandy, 2004.; Lees, 2003.).

\footnotetext{
${ }^{34}$ U slučajevima kada je razvijen socijalni kapital, usmerenost džentrifikatora prvenstveno na susedstvo, i njihovo oslanjanje na privatne usluge dovodi u pitanje kohezivnost grada.

35

Batler i Robson su analizirali džentrifikovana susedstva u Londonu ispitujući kako razvijenost socijalnog kapitala u susedstvu stvara različita susedstva srednje klase (Butler i Robson, 2001.).
} 


\subsection{Značaj simboličkog kapitala za proces džentrifikacije}

Sintetički oblik različitih vidova kapitala (ekonoskog, kulturnog i socijalnog) je simbolički kapital, a univerzalni oblik moći je simbolička moć, čiji je glavni sadržaj da stvarima i pojavama u društvenom prostoru da ime i značenje (Pavlović, 2006.:91). Imati moć imenovanja predstavlja najviši ili najznačajniji oblik političke, odnosno simboličke moći, jer se određivanjem imena, odnosno označavanjem, kreira i saznaje, odnosno osmišljava, održava i menja društveni svet (Pavlović, 2006.:94). Svaki oblik kapitala može se pretvoriti u simbolički ukoliko ispuni uslov spoznate i priznate socijalne legitimnosti, tako simbolički sloj ovih kapitala (simbolički kapital) ne predstavlja posebnu vrstu kapitala već označava vrednost koja nastaje zahvaljujući uzajamnom priznavanju statusnih odlika (Burdije, 1998.; Ignjatović, 2011.). Simbolički kapital se najčešće iskazuje kao prestiž, ugled ili slava. Učestvovanje u iniciranju procesa džentrifikacije ili izbor džentrifikovanog susedstva za stanovanje dovode se u vezu sa pripadnošću određenih statusnih grupa. U trenutku kada pojedinci ili domaćinstva počinju da izražavaju svoje stambene preferencije, tada susedstvo dobija na sve većem značaju u izražavanju statusa. Nečije boravište sve više utiče na određenje identiteta pojedinca. Proces biranja kojim ljudi odlučuju da žive u određenom mestu, a drugo da napuste, u središtu je savremenih borbi za socijalnim razlikovanjem (Savage et al., 2005.).

\section{Zaključak}

Ideje Pjera Burdijea mogu se primenjivati u proučavanju različitih aspekata fenomena džentrifikacije. Vrste kapitala (uloga kulturnog - institucionalizovanog, objektiviranog i otelovljenog; ekonomskog, socijalnog i simboličkog kapitala) doprinose boljem razumevanju nastanka ovog fenomena, kao i njegovog širenja (konverzija ekonomskog u kulturni kapital). Delovanje prvih džentrifikatora podstaknuto je njihovim kulturnim i socijalnim kapitalom. Ekspanzija procesa, prelaz pionirske u profitabilnu džentrifikaciju može se posmatrati, sledeći Burdijeovo shvatanje društvenih polja, kao posledica promena u različitim poljima i njihovih međusobnih odnosa. Povezivanje i preplitanje ekonomskih i kulturnih aktivnosti uticali su na usložnjavanje veza ekonomskog i kulturnog kapitala, i uspostavljanje drugačijeg odnosa između ekonomskog i umetničkog polja.

Kako fenomen džentrifikacije predstavlja značajan proces prostorne i društvene diferencijacije, Burdijeova klasna analiza omogućava određenje specifičnosti džentrifikatora kao socijalne grupe (frakcije, segmenta srednje klase, statusne grupe i sl.), ali i njihovu unutrašnju diferencijaciju. Akeri džentrifikacije mogu se posmatrati kao „frakcija klase” ili „deo klase” u burdijeovskom smislu distinkcije ukusa u odnosu na ostale pripadnike srednje klase. Kada se idealno tipski posmatra ukazuje se prvenstveno na razlike u okviru srednje klase između džentrifikatora i stanovnika suburbija, međutim, među samim džentrifikatorima, takođe, mogu se identifikovati razlike u pogledu vrste i količine kapitala koje poseduju, i uočiti varijacije životnih stilova i ukusa. Razlikovanje pionirske i profitabilne džentrifikacije ukazuje na socijalnu heterogenost džentrifikatora koja je vidljiva u njihovim drugačijim životnim 
stilovima. Osim toga, uočavanje dva tipa džentrifikacije omogućava razumevanje širenja procesa i nastanak različitih susedstava.

\section{Literatura}

1. Allen, C. and Blandy, S. (2004). Fables of the reconstruction: Inner-urban regeneration, city centre living and the reinvention of urban space, International conference Adequate \& Affordable Housing for All, Toronto. http://citeseerx.ist.psu.

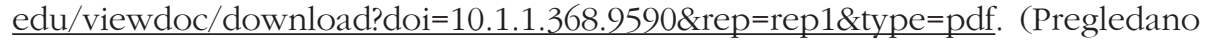
15.8.2014.)

2. Backović, V. (2016). Dominantni pristupi u proučavanju procesa džentrifikacije. Sociologija, 58 (3): 372-388.

3. Birešev, A. (2014). Orionov vodič. Beograd: Institut za filozofiju i društvenu teoriju.

4. Bridge, G. (2001a). Estate agents as interpreters of economic and cultural capital: the gentrification premium in the Sydney housing market. International Journal of Urban and Regional Research, 25 (1): 87-101.

5. Bridge, G. (2001b). Bourdieu, Rational Action and the Time-Space Strategy of Gentrification. Transactions of the Institute of British Geographers, 26 (2): 205216.

6. Bridge, G. (2006). Perspectives on Cultural Capital and the Neighbourhood. Urban Studies, 43 (4): 719-730.

7. Butler, T. and Robson, G. (2001). Social capital, gentrification and neighbourhood change in London: a comparison of three south London neighbourhoods. Urban Studies, 38 (12): 2145-2162.

8. Burdije, P. (1976). Klasna funkcija umetnosti. Kultura, 32: 90-113.

9. Burdije, P. (1998). Društveni prostor i simbolička moć, u: Spasić, I. (Ur.). Interpretativna sociologija. Beograd: Zavod za udžbenike i nastavna sredstva.

10. Burdije, P. (2003). Pravila umetnosti: geneza i struktura polja knjižeunosti. Novi Sad: Svetovi.

11. Burdije, P. (2004). Habitus i prostor stilova života. Kultura, 109-112: 131-170.

12. Burdije, P. (2013). Distinkcija. Podgorica: CID.

13. Burdije, P. i Paseron, Ž. (2014). Reprodukcija. Elementi za jednu teoriju obrazounog sistema. Beograd: Fabrika knjiga.

14. Cameron, C. and Coaffee, J. (2005). Art, Gentrification and Regeneration - From Artist as Pioneer to Public Arts. European Journal of Housing Policy, 5 (1): 39-58.

15. Čejni, D. (2003). Životni stilovi. Beograd: Clio.

16. Hannigan, J. (1995). The Postmodern City: A New Urbanism?. Current Socilogy, 43 (1): 151-217.

17. Filipović, B. (2014). Burdijeovo shvatanje nastanka i dinamike polja umetnosti. Teme, 3: 1019-1036.

18. Florida, R. (2002). The Rise of the Creative Class - And How It's Transforming Work, Leisure, Community and Everyday Life. New York: Basic Books.

19. Florida, R. (2005). Cities and the Creative Class, in: Lin, J. and Mele, C. (Eds.). The urban sociology reader. London: Routledge. 
20. Ignjatović, S. (2011). Socijalni kapital: od akademskih rasprava do javne politike. Beograd: Institut društvenih nauka.

21. Lees, L. (2003). Super-gentrification: the case of Brooklyn Heights, New York City. Urban Studies, 40 (12): 2487-2509.

22. Ley, D. (1996). The New Middle Class and the Remaking of the Central City. Oxford: Oxford University Press.

23. Ley, D. (2003). Artists, aestheticisation and the field of gentrification. Urban Studies, 40 (12): 2527-2544.

24. Pavlović, V. (2006). Burdijeov koncept simboličke moći i političkog kapitala, u: Nemanjić, M. i Spasić, I. (Ur.). Nasleđe Pjera Burdijea: pouke i nadabnuća. Beograd: Institut za filozofiju i društvenu teoriju: Zavod za proučavanje kulturnog razvitka.

25. Petrović, M. (2009). Transformacija gradova: ka depolitizaciji urbanog pitanja. Beograd: ISI FF.

26. Podmore, J. (1998). Re-reading the 'loft living' habitus in Montreal's inner city. International Journal of Urban and Regional Research, 22: 285-302.

27. Redfern, P. (2003). What Makes Gentrification ,Gentrification?. Urban Studies, 40 (12): 2351-2366.

28. Savage, M.; Bagnall, G. and Longhurst, B. (2005). Globalization and belonging. London: Sage.

29. Smith, N. (1979). Toward a Theory of Gentrification; a Back to the City Movement by Capital not People. Journal of the American Planning Association, 45: 538-48.

30. Smith, N. (2002). New Globalism, New Urbanism: Gentrification as Global Urban Strategy. Antipode, 34 (3): 427-450.

31. Spasić, I. (2006). Distinkcija na domaći način: diskursi statusnog diferenciranja u današnjoj Srbiji, u: Nemanjić, M. i Spasić, I. (Ur.). Nasleđe Pjera Burdijea: pouke i nadahnuća. Beograd: Institut za filozofiju i društvenu teoriju: Zavod za proučavanje kulturnog razvitka.

32. Tomanović, S. (2006). Primenljivost Burdijeovog koncepta socijalnog kapitala na proučavanje porodica u Srbiji, u: Nemanjić, M. i Spasić, I. (Ur.). Nasleđe Pjera Burdijea: pouke i nadabnuća. Beograd: Institut za filozofiju i društvenu teoriju: Zavod za proučavanje kulturnog razvitka.

33. Veblen, T. (2008). Teorija dokoličarkse klase. Novi Sad: Mediterran publishing.

34. Zukin, S. (1989). Loft Living: Culture and Capital in Urban Change. New Brunswick: Rutgers University Press.

35. Zukin, S. (1991). Landscapes of power: from Detroit to Disneyworld. Oxford: University of California Press.

36. Zukin. S. (1995). The Cultures of Cities. Blackwell.

37. Zukin. S. (1998). Urban Lifestyles: Diversity and Standardisation in Spaces of Consumption. Urban Studies, 35(5/6): 825-839.

38. Zukin. S. (2005). Whose Culture? Whose City?, in: Lin J. and C. Mele (Eds.). The urban sociology reader. London: Routledge. 
Vera Backović

University of Belgrade, Faculty of Philosophy, Serbia

e-mail:vera.backovic@f.bg.ac.rs

\title{
Contribution of Pierre Bourdieu's Theory to the Analysis of the Process of Gentrification
}

\begin{abstract}
The paper examines the possible application of Bourdieu's complex theory to the analysis of the gentrification process. The gentrification process changes the appearance and purpose of urban structures in the city core, which is followed by the changes of social characteristics of the people these structures are intended for. There are two types of gentrification: pioneer gentrification and profitable gentrification.

The occurrence, expansion and modification of the gentrification process can be explained as the result of the interaction of social fields. Gentrification could be seen as a process of distinction and then Bourdieu's class analysis determines the gentrifiers' class affiliation and recognizes their inner differentiation as well. In the paper special attention is paid to the role different types of capital (cultural, economic, social and symbolic) play in the process of gentrification.
\end{abstract}

Key words: pioneer gentrification, profitable gentrification, life style, cultural capital, economic capital. 